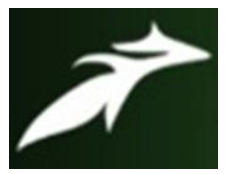

Shubham Manda et al, International Journal of Advances in Agricultural Science and Technology, Vol.8 Issue.8, August-2021, pg. 189-200

\title{
KNOWLEDGE OF MUSTARD GROWERS TOWARDS IMPROVED CULTIVATION PRACTICES IN SIRSA DISTRICT OF HARYANA
}

\author{
Shubham Manda ${ }^{1}$; Dipak Kumar Bose ${ }^{2}$, Jahanara ${ }^{3}$ \\ ${ }^{1}$ M.Sc. Ag. (Agricultural Extension and communication), SHUATS (Prayagraj) \\ ${ }^{2}$ Associate Professor, Department of Agriculture Extension and Communication, SHUATS (Prayagraj) \\ ${ }^{3}$ Head, Department of Agriculture Extension and Communication, SHUATS (Prayagraj) \\ Author's e-mail: shubhammanda9467959800@gmail.com \\ DOI: 10.47856/ijaast.2021.v08i8.021
}

Abstract: Increasing living standard of people arises the need for increased production of oilseed in country. But per capita availability of oil is very low, thus to increase the production of oil seed the farmers should adopt the new technology. Meanwhile, the research gap should be identified and rectified to increase the production. Thus, the knowledge and adoption level of respondents was studied to understand the complexity of technology adoption. Descriptive research design was adopted for the study. 120 respondents from six villages namely, Alanoor, Bhadra, Chamal, Dadu, Ffagu and Jamal of Sirsa block of Sirsa district in Haryana. The findings reported that majority of the respondents were middle aged, literate with middle school, had a land holding of 2.5-5 acres, nuclear family, agriculture as their major occupation along with service as their subsidiary occupation, medium level of annual income, had membership in more than one organization, medium level of risk orientation, medium level of knowledge, medium level of adoption.

Keywords: Mustard growers, Knowledge, Socio-economic profile, Improved cultivation practices

Introduction

Agriculture acts as key sector of Indian economy by contributing 28.00 per cent GDP. The fast growing population is putting tremendous pressure on the agricultural production in the country. The production per unit area is very low in comparison to other countries of the world. The oilseed sector has been an important area of concern and interventions for Indian policy makers in the post-reforms period when India became one of the largest importers of edible oils in the world, importing about half of domestic requirement in the 1990s (Sharma, 2014). The pre-requisites for agricultural development are the successful transfer of appropriate technology 


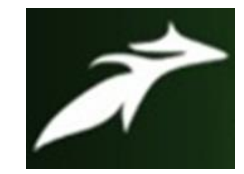

Shubham Manda et al, International Journal of Advances in Agricultural Science and Technology, Vol.8 Issue.8, August-2021, pg. 189-200

ISSN: 2348-1358

Impact Factor: 6.057

NAAS Rating: 3.77

from the scientists to the farmers. It has been realized that there is wide gap between what is achieved at the research stations and what farmers know and apply in the field.

Efforts have been made to transfer the technologies through various agencies of government of India and state government. China, India and Pakistan grow about 90\% of the world production of mustard. India contributes about 8-9 per cent of world's oilseeds production and is the fourth largest edible oil economy in the world. Oilseeds account for about 1.5 per cent of GDP and 8 per cent of values of all agricultural products. However, India ranks $3^{\text {rd }}$ in production of mustard. Total mustard area was 280.50 lakh ha, production of 327.49 lakh tones and yield of $1168 \mathrm{~kg} / \mathrm{ha}$, respectively during 2013-14 with an increase in more than 63 per cent in production and more than 29 per cent increase in yield than 2008-09. However, the area, production and productivity of oil seeds sharply declined to 258.24 lakh ha, 273.80 lakh tones and $1060 \mathrm{~kg} / \mathrm{ha}$ respectively during 20-21 mainly due to delayed and deficit rainfall.

India is one of the largest producers of rape seed and mustard in the world. India's contribution in the world rape seed and mustard is around 16.2 million tones which accounts for about 18 per cent of the oil seed production of the country. Mustard is the major rabi oil seed crop in India and important next to groundnut both in area and production. Mustard belong to genus brassica of the family brassicaceae. The oil seed brassica composed of four species, $B$. compestris, B. rapa, B.juncea (Indian Mustard), B. napus. Amongst oil seed crops grown in India, Brassica rank second in acreage with about 6.86 million hectare. Rape seed/mustard production is second rank and areas are first rank in India, etc.

Rape seed mustard oil is used primarily for cooking but there are species valued for vegetable fodder condiments and medicinal purpose. The oil obtained from various types varies from 30-40 percent. Rapeseed mustard is grown in as many as states in India. Although rapeseed-mustard is cultivated in 13 states of the country, bulk of the production takes place in four states including Rajasthan (45\%), Uttar Pradesh (13\%), Haryana (11\%) and West Bengal 


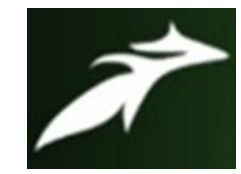

Shubham Manda et al, International Journal of Advances in Agricultural Science and Technology, Vol.8 Issue.8, August-2021, pg. 189-200

ISSN: 2348-1358

Impact Factor: 6.057

NAAS Rating: 3.77

(8\%) (Directorate of Rapeseed Mustard Research, 2015). In terms of rapeseed productivity, global ranking of India is 28 (Bhardwaj, 2013). Patel (2011) reported that majority of respondents had medium level of risk orientation, scientific orientation and economic motivation.

\section{Statement of problem}

The requirement of oilseed in country is rapidly increasing because of increasing population and people's living standard. But, per capita availability of oil is very low in India. Hence, the goal is to increase the farm production which can be achieved only, if the scientific agricultural technology is efficiently adopted at proper time and stage by the farmers, at their farm level. Due to complexity in different technology sometimes farmers find it hard to understand or remember all the operations as a result of which they lag behind in adoption of recommended package of practices. Thus, there arises a need to understand the knowledge level and adoption behaviour of mustard growers, to improve adoption thereby increasing the production and productivity of mustard. With this context, the following objectives of the study were formulated;

1. To assess the socio-economic profile of respondents.

2. To determine the knowledge of the respondents towards improved mustard cultivation practices.

\section{Methodology}

Descriptive research design is adopted in the study since the phenomenon was already occurred. This is appropriate as it aims to describe a population, situation or phenomenon accurately and systematically. Sirsa district of Haryana is selected purposely for the study because maximum area come under mustard and also the researcher belong to the area is well conversant with language, geography, agriculture and other aspect of the area. In Sirsa district of Haryana, there were 7 blocks. Out of which Sirsa block has been selected purposively because 


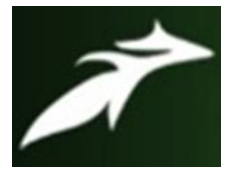

Shubham Manda et al, International Journal of Advances in Agricultural Science and Technology, Vol.8 Issue.8, August-2021, pg. 189-200

ISSN: 2348-1358

Impact Factor: 6.057

NAAS Rating: 3.77

maximum area come under mustard cultivation. In Sirsa block, there were 185 villages. Out of which 6 villages were selected namely, Alanoor, Bhadra, Chamal, Dadu, Fagu and Jamal. From the selected 6 villages of Sirsa block, 20 respondents were selected from each village. Thus, 120 respondents were selected from these 6 villages constitute the respondents of the study.

\section{Results and discussion}

The socio-economic profile of the respondents were studied under various characteristics and the results were presented under table.1.

Table.1. Socio-economic profile of the respondents $(n=120)$

\begin{tabular}{|c|c|c|c|c|}
\hline S. No. & Characteristics & Category & Frequency & Percentage \\
\hline \multirow[t]{3}{*}{1} & \multirow[t]{3}{*}{ Age (in years) } & Young $(<35)$ & 25 & 20.83 \\
\hline & & Middle(36-55) & 67 & 55.83 \\
\hline & & Old $(>55)$ & 28 & 23.34 \\
\hline \multirow[t]{7}{*}{2} & \multirow[t]{7}{*}{ Education } & Illiterate & 26 & 21.70 \\
\hline & & Literate (can read only) & 14 & 11.70 \\
\hline & & Primary school & 6 & 5.0 \\
\hline & & Middle school & 36 & 30.0 \\
\hline & & High school & 26 & 21.70 \\
\hline & & Intermediate & 8 & 6.70 \\
\hline & & Graduate and above & 4 & 3.30 \\
\hline \multirow[t]{4}{*}{3} & \multirow[t]{4}{*}{ Occupation } & Agriculture & 40 & 33.33 \\
\hline & & Agriculture +Services & 54 & 45.00 \\
\hline & & Agriculture +Labour & 24 & 20.00 \\
\hline & & Agriculture + Business & 2 & 1.70 \\
\hline \multirow[t]{2}{*}{4} & \multirow[t]{2}{*}{ Family type } & Nuclear family & 98 & 81.70 \\
\hline & & Joint family & 22 & 18.30 \\
\hline
\end{tabular}




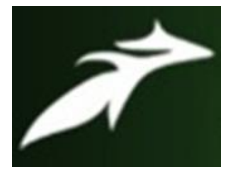

Shubham Manda et al, International Journal of Advances in Agricultural Science and Technology, Vol.8 Issue.8, August-2021, pg. 189-200

ISSN: 2348-1358

Impact Factor: 6.057

NAAS Rating: 3.77

\begin{tabular}{|c|c|c|c|c|}
\hline \multirow[t]{3}{*}{5} & \multirow[t]{3}{*}{ Land holding } & $<2.5$ acres & 14 & 11.70 \\
\hline & & 2.5-5 acres & 98 & 81.70 \\
\hline & & $>5$ acres & 8 & 6.60 \\
\hline \multirow[t]{3}{*}{6} & \multirow[t]{3}{*}{ Annual income } & Low (upto 50,000) & 24 & 20.00 \\
\hline & & Medium $(50,000-1$ lakh $)$ & 74 & 61.70 \\
\hline & & High ( above 1 lakh) & 22 & 18.30 \\
\hline \multirow[t]{4}{*}{7} & \multirow[t]{4}{*}{ Social participation } & $\begin{array}{l}\text { No membership in any } \\
\text { organization }\end{array}$ & 42 & 35.00 \\
\hline & & Membership in one organization & 24 & 20.00 \\
\hline & & $\begin{array}{c}\text { Membership in more than one } \\
\text { organization }\end{array}$ & 50 & 41.70 \\
\hline & & Office bearer & 4 & 3.30 \\
\hline \multirow[t]{3}{*}{8} & \multirow[t]{3}{*}{ Risk orientation } & Low & 6 & 5.0 \\
\hline & & Medium & 82 & 68.30 \\
\hline & & High & 32 & 26.70 \\
\hline
\end{tabular}

From table.1, it can be interpreted that more than half of the respondents were middle aged $(55.83 \%)$, followed by old age (23.34\%) and young age (20.83\%). Majority of the respondents were literate with middle school (30\%) education, followed by equal proportion of respondents were illiterate $(21.70 \%)$ and high school level of education $(21.70 \%)$, followed by literate (can read only) (11.70\%), Intermediate (6.70\%), primary school (5\%) and only 3.30 per cent were graduate and above. Majority of the respondents $(81.70 \%)$ had a land holding of 2.5-5 acres, followed by land holding of less than 2.5 acres $(11.70 \%)$ and only 6.60 per cent of the respondents had a land holding of more than 5 acres. Most of the respondents $(81.70 \%)$ had nuclear family, followed by 18.30 per cent of the respondents had joint family. 


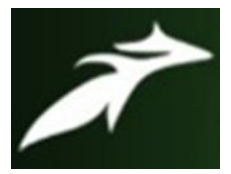

Shubham Manda et al, International Journal of Advances in Agricultural Science and Technology, Vol.8 Issue.8, August-2021, pg. 189-200

ISSN: 2348-1358 Impact Factor: 6.057

NAAS Rating: $\mathbf{3 . 7 7}$

Nearly half of the respondents (45\%) had agriculture as their major occupation along with service as their subsidiary occupation, followed by only agriculture $(33.33 \%)$ as their main occupation, 20 per cent of respondents had agriculture + labour as their main occupation and only 1.70 per cent consider agriculture + business as their occupation. More than half of the respondents $(61.70 \%)$ had medium level of annual income, followed by low (20\%) and high (18.30\%) level of annual income. Nearly half of the respondents (41.70\%) had membership in more than one organization, followed by 35 per cent of respondents had no membership in any organization, 20 per cent had membership in one organization and only 3.30 per cent of respondents were office bearer. Majority of the respondents $(68.30 \%)$ had medium level of risk orientation, followed by high (26.70\%) and low (5.0\%) level of risk orientation. Similar findings also reported by Vaidya (2011), Bhumia (2013), Chouhan et.al., (2013), Daur et.al., (2014), Sharma et.al., (2014), Singh et.al., (2014), Sharma et.al., (2015), Bagheril and Shabanali (2016), Hulgar (2018) and Dhore (2019).

The knowledge level of the respondents towards cultivation practices is identified, categorized and presented in table.2.

Table.2. Distribution of respondents based on their knowledge level towards improved cultivation practices

\begin{tabular}{|c|c|c|c|c|c|c|c|}
\hline \multirow{3}{*}{$\begin{array}{c}\text { S. } \\
\text { No. }\end{array}$} & \multirow[t]{3}{*}{ Statement } & \multicolumn{6}{|c|}{ Response } \\
\hline & & \multicolumn{2}{|c|}{ Fully correct } & \multicolumn{2}{|c|}{ Partially correct } & \multicolumn{2}{|c|}{ Not correct } \\
\hline & & $f$ & $\%$ & $f$ & $\%$ & $f$ & $\%$ \\
\hline 1. & $\begin{array}{l}\text { Field preparation: } \\
\text { - } \quad \text { Traditional method- 2- } \\
\text { - } 3 \text { times ploughing } \\
\text { Use of zero tillage } \\
\text { machine } \\
\text { - } \quad \text { Surface seeding } \\
\text { method } \\
\text { - Seed driller }\end{array}$ & 34 & 28.30 & 46 & 38.40 & 40 & 33.30 \\
\hline
\end{tabular}




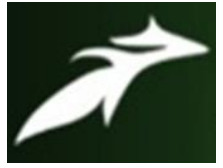

Shubham Manda et al, International Journal of Advances in Agricultural Science and Technology, Vol.8 Issue.8, August-2021, pg. 189-200

ISSN: 2348-1358

Impact Factor: 6.057

NAAS Rating: 3.77

\begin{tabular}{|c|c|c|c|c|c|c|c|}
\hline 2. & \begin{aligned} & \multicolumn{2}{l}{ Improved variety: } \\
& I. PBR 210 \\
& II. Sriram1666 \end{aligned} & 15 & 12.50 & 75 & 62.50 & 30 & 25.00 \\
\hline 3. & 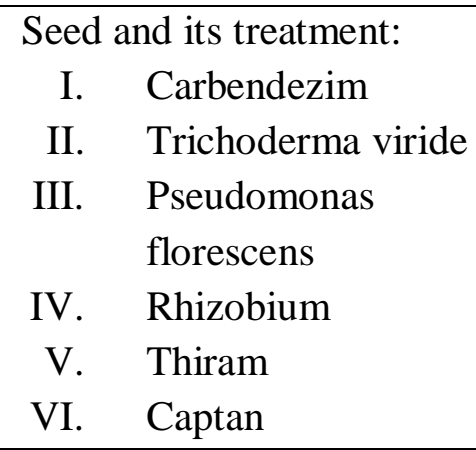 & 29 & 24.17 & 57 & 47.50 & 34 & 28.33 \\
\hline 4. & $\begin{array}{l}\text { Sowing time } \\
\text { - September last } \\
\text { - October first }\end{array}$ & 8 & 6.60 & 98 & 81.70 & 14 & 11.70 \\
\hline 5. & $\begin{array}{l}\text { Spacing } \\
\text { I. } \quad 30 \times 10 \mathrm{~cm}\end{array}$ & 12 & 10.00 & 73 & 60.83 & 35 & 29.17 \\
\hline 6. & $\begin{array}{l}\text { Fertilizers: } \\
\text { NPK : 40:25:ZnSO4 }\end{array}$ & 14 & 11.67 & 77 & 64.17 & 29 & 24.17 \\
\hline 7. & \begin{aligned} & \multicolumn{2}{l}{ Irrigation: } \\
& I. 0 times \\
& II. 1 times \\
& III. 2 times \\
& IV. 3 times \\
& V. 5times \end{aligned} & 21 & 17.50 & 59 & 49.17 & 38 & 31.67 \\
\hline 8. & $\begin{array}{l}\text { Weeding and hoeing } \\
\text { operations: } \\
\text { I. } \quad 2 \text { times } \\
\text { II. } \quad 3 \text { times } \\
\text { III. } \quad 4 \text { times }\end{array}$ & 27 & 22.50 & 62 & 51.7 & 31 & 25.83 \\
\hline 9. & \begin{aligned} & \multicolumn{2}{l}{ Weed control: } \\
& I. Vernolate \\
& II. Acetochlor \\
& III. Alachlor \\
& IV. Pendimethaline \end{aligned} & 12 & 10.00 & 57 & 47.50 & 51 & 42.50 \\
\hline
\end{tabular}




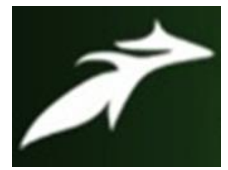

Shubham Manda et al, International Journal of Advances in Agricultural Science and Technology, Vol.8 Issue.8, August-2021, pg. 189-200

ISSN: 2348-1358

Impact Factor: 6.057

NAAS Rating: 3.77

\begin{tabular}{|c|c|c|c|c|c|c|c|}
\hline 10. & \begin{aligned} & \multicolumn{2}{l}{ Diseases: } \\
& I. Stem rot \\
& II. Pod and Stem blight \\
& III. Brown spot \\
& IV. Downy mildew \end{aligned} & 17 & 14.16 & 84 & 70.00 & 19 & 15.83 \\
\hline 11. & \begin{tabular}{ll}
\multicolumn{3}{l}{ Harvesting: } \\
I. & 80-90days \\
II. & $90-100$ days \\
III. & $100-110$ days \\
IV. & $110-120$ days
\end{tabular} & 24 & 20.00 & 69 & 57.50 & 27 & 22.50 \\
\hline 12. & $\begin{array}{cl}\text { Yield: } & \\
\text { I. } & \text { 35-40quintal/ha } \\
\text { II. } & 20-25 \text { quintal } / \text { ha } \\
\text { III. } & 15-20 \text { quintal/ha } \\
\text { IV. } & \text { 25-35quintal/ha }\end{array}$ & 15 & 12.50 & 72 & 60.00 & 33 & 27.50 \\
\hline 13. & $\begin{array}{l}\text { Soil: } \\
\text { I. Loamy } \\
\text { II. Sandy Loamy } \\
\text { III._Clay }\end{array}$ & 12 & 10.00 & 63 & 52.50 & 45 & 37.50 \\
\hline 14. & $\begin{array}{l}\text { Weed control: } \\
\text { I. Pre-emergent } \\
\text { II. post emergent }\end{array}$ & 6 & 5.00 & 83 & 69.17 & 31 & 25.83 \\
\hline 15. & $\begin{array}{l}\text { Soil } \mathrm{Ph} \\
\text { I. } 6.0 \\
\text { II. } 6.5 \\
\end{array}$ & 28 & 23.33 & 47 & 39.17 & 45 & 37.50 \\
\hline
\end{tabular}

From table.2, it was reported that 28.30 per cent, 38.40 per cent and 33.30 per cent of respondents had fully correct, partially correct and no correct knowledge on field preparation. Whereas, 12.50 percent, 62.50 per cent and 25 per cent of respondents had fully correct, partially correct and no correct knowledge on improved variety. 24.17 percent, 47.50 per cent and 28.33 per cent of respondents had fully correct, partially correct and no correct knowledge on seed and its treatment. 6.60 percent, 81.70 per cent and 11.70 per cent of respondents had fully correct, 


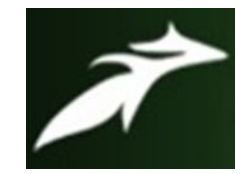

Shubham Manda et al, International Journal of Advances in Agricultural Science and Technology, Vol.8 Issue.8, August-2021, pg. 189-200

ISSN: 2348-1358

Impact Factor: 6.057

NAAS Rating: 3.77

partially correct and no correct knowledge on sowing time. 10 percent, 60.83 per cent and 29.17 per cent of respondents had fully correct, partially correct and no correct knowledge on spacing.

Meanwhile, 11.67 percent, 64.17 per cent and 24.17 per cent of respondents had fully correct, partially correct and no correct knowledge on fertilizers. 17.50 percent, 49.17 per cent and 31.67 per cent of respondents had fully correct, partially correct and no correct knowledge on irrigation. 22.50 percent, 51.70 per cent and 25.83 per cent of respondents had fully correct, partially correct and no correct knowledge on weeding and hoeing operations. 10 percent, 47.50 per cent and 42.50 per cent of respondents had fully correct, partially correct and no correct knowledge on weed control. 14.17 percent, 70 per cent and 15.83 per cent of respondents had fully correct, partially correct and no correct knowledge on diseases.

Eventually, 20 percent, 57.50 per cent and 22.50 per cent of respondents had fully correct, partially correct and no correct knowledge on harvesting. 12.50 percent, 60 per cent and 27.50 per cent of respondents had fully correct, partially correct and no correct knowledge on yield. 10 percent, 52.50 per cent and 37.50 per cent of respondents had fully correct, partially correct and no correct knowledge on soil. 5 percent, 69.17 per cent and 25.83 per cent of respondents had fully correct, partially correct and no correct knowledge on weed control. 23.33 percent, 39.17 per cent and 37.50 per cent of respondents had fully correct, partially correct and no correct knowledge on soil $\mathrm{pH}$.

The overall knowledge level of the respondents towards cultivation practices is identified, categorized and presented in table.3. 


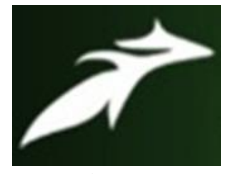

Shubham Manda et al, International Journal of Advances in Agricultural Science and Technology, Vol.8 Issue.8, August-2021, pg. 189-200

ISSN: 2348-1358

Impact Factor: 6.057

NAAS Rating: 3.77

Table.3. Overall knowledge level of respondents towards improved cultivation practices

$(\mathbf{n}=\mathbf{1 2 0})$

\begin{tabular}{|c|c|c|c|}
\hline S. No. & Category & Frequency & Per cent \\
\hline 1 & Low & 12 & 10.00 \\
\hline 2 & Medium & 60 & 50.00 \\
\hline 3 & High & 48 & 40.00 \\
\hline
\end{tabular}

From table.3, it could be learnt that half of the respondents had medium level of knowledge (50\%), followed by high (40\%) and low (10\%) level of knowledge.

The relationship between socio-economic profile and knowledge level of respondents towards improved cultivation practices was studied and presented in table.4.

Table.4. Association between socio-economic profile and knowledge level of respondents towards improved cultivation practices

\begin{tabular}{|c|c|c|c|c|c|}
\hline $\begin{array}{c}\text { S. } \\
\text { No. }\end{array}$ & Characteristics & 'r' value & $\begin{array}{l}\text { Regression } \\
\text { co-efficient }\end{array}$ & $\begin{array}{c}\text { Standard } \\
\text { error }\end{array}$ & t-value \\
\hline $\mathrm{X}_{1}$ & Age & $0.012 *$ & $1.326^{*}$ & 0.596 & $0.031 *$ \\
\hline $\mathrm{X}_{2}$ & Education & 0.729 & 0.580 & 2.373 & 0.808 \\
\hline $\mathrm{X}_{3}$ & Occupation & 0.354 & 5.408 & 7.942 & 0.499 \\
\hline $\mathrm{X}_{4}$ & Land holding & 0.541 & 4.065 & 5.590 & 0.471 \\
\hline $\mathrm{X}_{5}$ & Annual Income & $0.027 *$ & $6.372 * *$ & 0.000 & $0.131 * *$ \\
\hline $\mathrm{X}_{6}$ & Social participation & $0.404 * *$ & $-3.805^{*}$ & 1.774 & $0.037 *$ \\
\hline
\end{tabular}




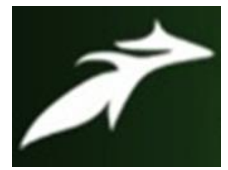

Shubham Manda et al, International Journal of Advances in Agricultural Science and Technology, Vol.8 Issue.8, August-2021, pg. 189-200

ISSN: 2348-1358

Impact Factor: 6.057

NAAS Rating: 3.77

\begin{tabular}{|c|l|c|c|c|c|}
\hline $\mathrm{X}_{7}$ & Risk orientation & $0.022^{*}$ & $3.863 *$ & 1.894 & $0.047 *$ \\
\hline $\mathrm{X}_{8}$ & Family type & 0.857 & -2.986 & 0.000 & 0.620 \\
\hline
\end{tabular}

$\mathbf{R}^{2}=\mathbf{0 . 4 5 9}$

$\mathbf{F}=\mathbf{2 . 7 3 2}$

$\mathbf{a}=\mathbf{1 5 1 . 6 7 7}$

NS $=$ Not Significant $*=$ Significant at $5 \%, * *=$ Significant at $10 \%$.

From table.4, it can be seen that socio-economic characteristics like age, annual income and risk orientation had positive and significant association with the knowledge level of respondents towards improved cultivation practices at 5 per cent level of significance; social participation had positive and significant association with the knowledge level at 10 per cent level of significance. Meanwhile, education, occupation, land holding and family type had nonsignificant association with the knowledge level of respondents towards improved cultivation practices.

\section{CONCLUSION}

Majority of the respondents were middle aged, literate with middle school, had a land holding of 2.5-5 acres, nuclear family, agriculture as their major occupation along with service as their subsidiary occupation, medium level of annual income, had membership in more than one organization, medium level of risk orientation, medium level of knowledge. Socio-economic characteristics like age, annual income, social participation and risk orientation had positive and significant association; education, occupation, land holding and family type had non-significant association with the knowledge level of respondents towards improved cultivation practices. 


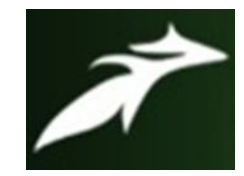

Shubham Manda et al, International Journal of Advances in Agricultural Science and Technology, Vol.8 Issue.8, August-2021, pg. 189-200

ISSN: 2348-1358

Impact Factor: 6.057

NAAS Rating: 3.77

\section{REFERENCES}

[1]. Bagheri, A and Shabanali, Fami H. (2016). "Potato growers' Risk perception: A case study in Ardabil Province of Iran" Journal of agri. Science and Technology. 18: 55-65.

[2]. Bhardwaj V. 2013. Overview of Indian Oilseed Sector; How to increase rapeseed production to reach 10 million tonnes. A presentation in National Council of Applied Economic Research (NCAER) and The Solvent Extractors 'Association of India (SEA) held at New Delhi 15th March.

[3]. Bhumia (2013) concluded that maximum respondents $(76.36 \%)$ had medium level of social participation.

[4]. Chouhan, Sandeep, Sigh, S.R.K., Pande, A.K. and Gautam, U.S. 2013. Adoption dynamics of improved sugarcane cultivation in Madhya Pradesh. Indian Research Journal of Extension Education. 13(2):26-30.

[5]. Daur, D.S., Choudhary and Swarnakar, V.K. 2014. Study on knowledge and adoption level of soybean growers through Front Line Demonstrations (FLD's) in Ujjain district of M.P. M.Sc. (Ag.) Thesis, College of Agriculture, Indore, RVSKVV, Gwalior.

[6]. Dhore, R. K., Pavan Kumar, P., and S. N. Singh. 2019. Profile characteristics of farmer in Adoption of Bt. Cotton.Int. J.Curr. Microbiol. App. Sci. 8(01): 2373-2378.

[7]. Directorate of Rapeseed-Mustard Research (DRMR). 2015. Vision-2030 Document. http://www.drmr.res.in/drmr/

[8]. Sharma V P. 2014. Report on 'Problems and prospects of oilseeds production in India'. Centre for Management in Agriculture (CMA), Indian Institute of Management (IIM) Ahmedabad. https:// www.iima.ac.in/c/document_library/get_file?uuid=981f4ee1-2595-4090-a56373fc703e5118\&groupId $=62390$

[9]. Hulagar, B., J. Tulasiram, and G.N Maraddi, 2018. A study on Adoptipon level of recommended cultivation practices of Black gram growers in North Eastern Karnataka, India. Int. J. Curr. Microbiol. App. Sci., 7(2): 567-574.

[10].Sharma, Kramjit, Dhaliwal, N.S. and Kumar, Ajay. 2015. Analysis of adoption and constraints perceived by small paddy growers in rice production technologies in Muktsar District of Punjab State, India. Indian Research Journal of Extension Education. 15(2):20-23. 